\title{
A Review on Vaccination Drive for COVID-19 in India
}

\author{
Yukta $^{1}$, R.K Patil ${ }^{2}$, H.C Patil ${ }^{3}$ \\ ${ }^{1}$ Pharm.D (Student), Adesh institute of Pharmacy and Biomedical Sciences, Bathinda \\ ${ }^{2}$ Professor, Department of Pharmacy Practice, Adesh Institute of Pharmacy and Biomedical Sciences, Bathinda \\ ${ }^{3}$ Professor \& Principal, Adesh Institute of Pharmacy and Biomedical Sciences, Bathinda
}

Corresponding Author: Yukta

\begin{abstract}
The Covid-19 pandemic is destructing the whole world rapidly and also results in changing the order of human life. Various strategies and efforts are being applied by health experts to fight against the pandemic. Various vaccines are developed by researchers of different countries. The aim for developing the vaccines is to produce Herd immunity i.e. to resist the spread of SARS-CoV-2 virus. 8-12 years are required for the development of vaccine in normal circumstances but in emergency like Covid-19 pandemic vaccines get ready in 10 months by various methods like viral vector vaccines, mRNA based vaccines, inactivated vaccines. In India only three vaccines i.e. Covaxin, Covishield, and Sputnik-V get the Emergency Use Authorisation (EUA) from the drug controller general of India (DCGI). Vaccines vary in their efficacy that's why only few vaccines get the emergency approval across the globe. These vaccines also show mild to moderate and in some case rare adverse effects.
\end{abstract}

Key Words - Pandemic, Vaccines, Covid-19, Herd immunity, Adverse effects

\section{INTRODUCTION}

The whole world is facing the pandemic viral disease which is caused by the SARS-Cov-2. This COVID-19 disease was first detected in Wuhan, China, in December 2019. ${ }^{[1]}$ The COVID-19 has emerged as a respiratory disease. Patients who suffered from this novel corona virus has shown symptoms like pneumonia, which may be mild to moderate, also shows symptoms of acute respiratory distress syndrome, septic shock, and multiple organ failure. ${ }^{[2]}$ Higher incidence of cardiovascular diseases have been reported in patients suffering from COVID-19. Several studies noted that COVID-19 activates coagulation pathways and endothelial cell dysfunction which results in cardiac arrest and cardiomyopathy in patients. ${ }^{[3]}$ Sectors like travel, tourism, hospitality, economic get adversely affected worldwide due to this pandemic.
Now, there is a need to strengthen the individual's immune system to get protection from COVID-19. ${ }^{[4]}$ The biggest coronavirus vaccination programme around the globe has launched on January 16,2021 by India. The first priority of vaccination was given to frontline workers of health, education and police. The second priority is given to other people of the country. It is very important for individuals to get vaccinated as soon as possible as this the only way for achieving 'herd immunity' in the country. Two vaccines - Covishield and Covaxin are the part of vaccination programme in India. ${ }^{[5]}$ Study of evaluation of covid-19 patients affirmed that antibody binder and main bidders attacks on the receptor-binding domain subunit $\mathrm{S} 1$. The immunization generates an effective immune response in the human body which is characterized by formation of neutralizing 
antibodies, formation of t-cells response and prevention of disease. ${ }^{[6]}$

Types of vaccines - as soon as the coronavirus infection found in the world, the researchers started their work in laboratories to make sequences of gene of SARS-CoV-2 virus for identifying the targets to develop vaccine. Vaccine availability is important to develop Herd immunity in the population. Herd immunity refers to the resistance of the transmission of an infectious disease within the population which develops when majority of the population get immune. So, the Herd immunity is necessary to slow the transmission rate of covid-19 disease. Many vaccines are developed by the scientists across the globe from which only few vaccines get the authorization for emergency use in pandemic. Researchers developed these vaccines through various technologies. The vaccine gets the authorisation after conducting the clinical trials in various phases to evaluate the safety and efficacy of the vaccine. Efficacy limit of $50 \%$ has been set by WHO to get the approval for vaccine. ${ }^{[7,8]}$

\begin{tabular}{|c|c|c|c|}
\hline Inactivated virus & Protein subunit & Viral vector & Nucleic acids \\
\hline $\begin{array}{l}\text { Inactivated vaccines obtained } \\
\text { through virus grown in culture and } \\
\text { then virus get inactivated } \\
\text { chemically, which releases stably } \\
\text { expressed, conformationally native } \\
\text { antigenic epitopes. } \\
\text { It is also obtained by inactivating the } \\
\text { virus through ultraviolet rays by } \\
\text { laboratory biosafety level } 3 \text { (BSL3). } \\
\text { It includes steps like expansion, } \\
\text { titration, inactivation and } \\
\text { ultracentrifugation of the virus. }{ }^{[6,9,10]}\end{array}$ & $\begin{array}{l}\text { Developed by inducing } \\
\text { protein S subunit as a } \\
\text { recombinant protein } \\
\text { subunit within the cell } \\
\text { based systems. Risk is } \\
\text { development of polarized } \\
\text { immune system. }\end{array}$ & $\begin{array}{l}\text { Developed by genetically } \\
\text { engineered weakened viruses such } \\
\text { as rubeola, adenovirus or measles } \\
\text { to produce coronavirus proteins in } \\
\text { the body. There are two types of } \\
\text { vaccines - replicating and non } \\
\text { replicating viral vector } \\
\text { vaccines. }\end{array}$ & $\begin{array}{l}\text { Immune response is produced } \\
\text { by inducing the genetic } \\
\text { information i.e. by nucleic } \\
\text { acids in the form of RNA and } \\
\text { DNA into human cells and } \\
\text { then copies of virus's spike } \\
\text { proteins are formed in the } \\
\text { body. }{ }^{[1]}\end{array}$ \\
\hline
\end{tabular}

\section{Vaccines across the globe ${ }^{[6,11,13,14]}$}

\begin{tabular}{|c|c|c|c|c|c|}
\hline Type & Vaccine & Mechanism & Dose & Storage & Efficacy \\
\hline \multirow[t]{3}{*}{$\begin{array}{l}\text { Inactivated } \\
\text { virus }\end{array}$} & $\begin{array}{l}\text { CoronaVac } \\
\text { (sinovacbiotech,china) }\end{array}$ & $\begin{array}{l}\text { Inactivated } \mathrm{CNO} 2 \\
\text { Strain created from vero cells of covid-19 } \\
\text { virus. }\end{array}$ & $\begin{array}{l}3 \mu \mathrm{g} \\
(2 \text { doses in } 14 \\
\text { days })\end{array}$ & $2-8^{\circ} \mathrm{C}$ & $50 \%$ \\
\hline & $\begin{array}{l}\text { BBIBP-CorV } \\
\text { (sinopharm } 1 / 2, \text { china) }\end{array}$ & $\begin{array}{l}\text { Inactivated } \mathrm{HBO} 2 \text { strain created from } \\
\text { vero cells of virus. }\end{array}$ & $\begin{array}{l}4 \mu \mathrm{g} \\
(2 \text { doses in } 21 \\
\text { days })\end{array}$ & $2-8^{\circ} \mathrm{C}$ & $79 \%$ \\
\hline & $\begin{array}{l}\text { BB15V2 / } \\
\text { Covaxin } \\
\text { (Bharatbiotech, India) }\end{array}$ & $\begin{array}{l}\text { Inactivated covid-19 virus with a beta- } \\
\text { propiolactone chemical }\end{array}$ & $\begin{array}{l}2 \text { doses in } 28 \\
\text { days }\end{array}$ & $2-8^{\circ} \mathrm{C}$ & $81 \%$ \\
\hline \multirow[t]{3}{*}{ Viral vector } & $\begin{array}{l}\text { Ad26.COV2. S } \\
\text { (Johnson \& Johnson, US) }\end{array}$ & $\begin{array}{l}\text { Adenovirus vector with spike protein of } \\
\text { covid-19 virus. }\end{array}$ & $\begin{array}{l}5 \times 10^{10} \quad \text { viral } \\
\text { particles } \\
(1 \text { dose })\end{array}$ & $\begin{array}{l}2-8^{\circ} \mathrm{C} \\
\text { months }) ; \\
-20^{\circ} \mathrm{C}(2 \mathrm{yrs})\end{array}$ & $72 \%$ \\
\hline & $\begin{array}{l}\text { ChAdOx1/A ZD1222 } \\
\text { [Covishield] } \\
\text { (Oxford/Astra Zeneca, UK) }\end{array}$ & $\begin{array}{l}\text { Adenovirus vector with spike protein of } \\
\text { covid-19 virus. }\end{array}$ & $\begin{array}{l}5 \times 10^{10} \text { viral } \\
\text { particles } \\
(2 \text { doses in } 28 \\
\text { days })\end{array}$ & $\begin{array}{l}2-8^{\circ} \mathrm{C} \\
\text { months })\end{array}$ & $82 \%$ \\
\hline & $\begin{array}{l}\text { Sputnik V / Gam-CovidVac } \\
\text { (Gamaleya, Russia) }\end{array}$ & $\begin{array}{l}\text { Adenovirus vector with spike protein of } \\
\text { covid-19 virus. }\end{array}$ & $\begin{array}{l}10^{11} \text { viral } \\
\text { particles } \\
(2 \text { doses in } 21 \\
\text { days) }\end{array}$ & $\begin{array}{l}2-8^{\circ} \mathrm{C} \\
\text { months }) ; \\
-20^{\circ} \mathrm{C} \\
(2 \mathrm{yrs})\end{array}$ & $91.6 \%$ \\
\hline $\begin{array}{l}\text { Protein } \\
\text { subunit }\end{array}$ & $\begin{array}{l}\text { NVXCov2373 } \\
\text { (Novovax, US) }\end{array}$ & $\begin{array}{l}\text { Recombinant full length, perfusion } \mathrm{S} \\
\text { protein }\end{array}$ & $\begin{array}{l}5 \mu g+50 \mu \mathrm{g} \\
(2 \text { doses })\end{array}$ & $\begin{array}{l}2-8^{\circ} \mathrm{C} \\
\text { months })\end{array}$ & $86 \%$ \\
\hline \multirow[t]{3}{*}{$\begin{array}{l}\text { mRNA } \\
\text { vaccine }\end{array}$} & $\begin{array}{l}\text { mRNA1273 } \\
\text { (moderna, US) }\end{array}$ & $\begin{array}{l}\text { Encoded mRNA with spike protein in } \\
\text { lipid nanoparticle. }\end{array}$ & $\begin{array}{l}100 \mu \mathrm{g} \\
(2 \text { doses in } 28 \\
\text { days })\end{array}$ & $\begin{array}{l}-25 \text { to }-15^{\circ} \mathrm{C} \\
2-8^{\circ} \mathrm{C} \text { for } 30 \\
\text { days }\end{array}$ & $94 \%$ \\
\hline & $\begin{array}{l}\text { BNT162b2 } \\
\text { (Pfizer-BioNtech, US) }\end{array}$ & $\begin{array}{l}\text { Encapsulated in lipid nanoparticles with } \\
\text { mRNA and spike protein. }\end{array}$ & $\begin{array}{l}30 \mu \mathrm{g} \\
(2 \text { doses in } 21 \\
\text { days })\end{array}$ & $\begin{array}{l}-80 \text { to }-60^{\circ} \mathrm{C} ; \\
2-8^{\circ} \mathrm{C} \text { for } 5 \\
\text { days }\end{array}$ & $95 \%$ \\
\hline & $\begin{array}{l}\text { CVnCoV } \\
\text { (GlaxoSmithKline, } \\
\text { Germany) }\end{array}$ & $\begin{array}{l}\text { Stabled and perfused length of } \mathrm{S} \text { protein } \\
\text { of virus. }\end{array}$ & $\begin{array}{l}12 \mu \mathrm{g} \\
(2 \text { doses in } 28 \\
\text { days })\end{array}$ & $\begin{array}{l}2-8^{\circ} \mathrm{C} \text { for } 6 \\
\text { months }\end{array}$ & unknown \\
\hline
\end{tabular}




\section{Vaccines in India}

A huge vaccination drive in India has been started on $16^{\text {th }}$ January 2021 with two vaccines Covishield and Covaxin but on $1^{\text {st }}$ May 2021 India has received the first lot of third vaccine i.e. Sputnik V from Russia. The drugs controller general of India has approved these vaccines for public use. The government of India has decided to vaccinate the population above 18yrs of age by august 2021. Vaccination is contraindicated in pediatric age group, pregnant and lactating women but can be extended after ensuring post marketing surveillance results of the vaccines. ${ }^{[15,16]}$

1. Covishield vaccine - This is a viral vector vaccine which is manufactured by the Serum institute of India but developed by Astra Zeneca with Oxford university, UK and labelled as AZD1222.Immune response is generated by using the recombinant technology which is used to deliver the adenoviral vector (ChAdOx1) from chimpanzees containing glycoprotein antigen of spike protein of Covid-19 virus. ${ }^{[7,15]} 0.5 \mathrm{ml}$ dose of vaccine is administered in people and it requires $2^{\circ} \mathrm{C}-8^{\circ} \mathrm{C}$ storage requirements. Studies of interim analysis shows that efficacy of vaccine after $1^{\text {st }}$ dose is $62 \%$ and after $2^{\text {nd }}$ dose it is near about $90 \%$. In some studies it is noticed that after $1^{\text {st }}$ dose at $14^{\text {th }}$ day the $\mathrm{T}$-cell response is high and at $28^{\text {th }}$ day the anti-spike $\operatorname{IgG}$ antibody response is high so the $2^{\text {nd }}$ dose for boosting effect is given between 4 to 8 weeks of first dose after which neutralising antibody effect is generated in the body. ${ }^{[8,14,17]}$

2. Covaxin vaccine- Bharat Biotech manufactured this vaccine in collaboration with ICMR (Indian Council of Medical Research). The immune system from this vaccine is generated by inactivated whole virion of SARS-CoV-2. ${ }^{[15,17]}$ It is labelled as BBV152. Bharat Biotech received the isolated and sequenced virus strain from ICMR-NIV (National Institute of Virology) to develop Covaxin which is then formulated with TLR 7/8 agonist molecule absorbed to alhydroxiquim-II (algel IMDG). $0.5 \mathrm{ml}$ dose is administered intramusculary in each dose and it requires $2^{\circ} \mathrm{C}-8^{\circ} \mathrm{C}$ temperature for storage. Th1-biased response was reported in first phase clinical trial of BBV152 vaccine and it is the first vaccine which induced this response and in $2^{\text {nd }}$ phase trial the T-cell memory response was induced. Due to strong production of cell mediated and humoral antibody response, it is hypothesised that immune response may last for 12 months after the $2^{\text {nd }}$ dose. ${ }^{[18,19]}$ According to ICMR the multiple variants and double mutant strain of SARS-CoV-2 virus has been found in India gets neutralised by Covaxin. ${ }^{[20]}$

3. Sputnik-V Vaccine - Gamaleya National Center of Epidemiology and Microbiology in Russia has developed Sputnik-V Covid19 Vaccine which was recently approved by India for its population. ${ }^{[21]}$ Sputnik-V is a viral vector vaccine based on heterologous recombinant adenovirus (rAd), which contains the combination of two viral vectors i.e. rAd type 26 (rAd26)18 and rAd type 5 (rAd5).rAd5 and rAd26 comprises a gene of spike protein $\mathrm{S}$ of Covid-19 virus and it becomes rAd5-S and rAd26-S. rAd26-S is given as first dose and rAd5-S is given as second dose. ${ }^{[22,23,24]}$ It requires the 21 days interval between first dose and second dose and $0.5 \mathrm{ml}$ is administered intramuscularly into the deltoid muscle in each dose. Single immunisation of viral vector vaccines like Covishield and sputnik$\mathrm{v}$ may induce cellular and humoral immunity both, that's why these vaccines are allowed in pandemic as a emergency prophylaxis tool. In addition of double immunisation produce long lasting immunity. The interim analysis shows that vaccine's efficacy is about $91.6 \%$ against covid-19. ${ }^{[21,22]}$ Earlier in the month of April the study of Argentina shows that people had those antibodies in their body after the completion of both the doses of Sputnik-V which are effective against the UK variant B.1.1.7 variant. ${ }^{[21,25]}$ 
Adverse effects of vaccines -

\begin{tabular}{|l|l|l|}
\hline Local side effect & Systemic side effect & Rare side effects \\
\hline Redness at injection site & Fever & Appendicitis \\
Swelling at injection site & Headache & Thromboembolism \\
Pain in arm for 3 days & Chills & Myocardial infarction \\
Rashes on arm & Vomiting & Cerebrovascular accident \\
Itching on arm for 3 days & Diarrhoea & Shoulder injury \\
& Body pain & \\
& Lymphadenopathy & \\
& Joint pain & \\
& Bell's palsy (sudden weakness in the muscles of half of the face) & \\
& Myalgia & \\
& Dizziness & \\
& Vertigo & \\
& Palpitation & \\
& Chest pain for 1 day & \\
\hline
\end{tabular}

\section{Thromboembolism a rare side effect of Covishield-}

Many European countries had banned the Covishield (AZD1222) vaccine for their population because cases of thromboembolism (formation of blood clot) had reported after vaccination. 5 million people had received the ChAdOx1-nCoV-19 in European area by march 2021 but 30 cases from this had been reported of thromboembolism. ${ }^{[26,27]}$ In early march Germany had reported 9 cases of thrombocytopenia and intra cranial venous sinus thrombosis in recipients of OxfordAstraZeneca vaccine against the covid-19 pandemic. ${ }^{[28]}$ In UK 20 million people had received Covishield vaccine and among these 79 individual had been reported with thromboembolism with thrombocytopenia and with 19 causalities. The study of new England journal of medicine also shows that there are 11 patients of median age of $36 \mathrm{yrs}$ had developed thromboembolism between 5 to 16 days after vaccination. The researchers had tested their blood samples and blood samples showed the presence of antibodies against platelet factor 4 (PF4) with no previous exposure of heparin but researchers cannot concluded the study yet that whether these antibodies are autoantibodies which are produced by vaccination as an inflammatory stimulus or vaccine produced these antibodies which cross react with platelet factor 4 and platelets. After the observations researchers suggested that thromboembolism with thrombocytopenia due to Oxford AstraZeneca vaccine is a rare immune response which is similar with heparin induced thrombocytopenia i.e. a rare side effect due to heparin. On April 7, 2021 the UK's Expert Haematology Panel has suggested the use of intravenous immunoglobulin, avoiding platelet transfusions, and non-heparin blood thinners as a management therapy for thrombosis and thrombocytopenia induced after vaccination. ${ }^{[29,30]}$

\section{CONCLUSION}

Vaccination is the only way to achieve protective level of Herd immunity against COVID-19 infection. Vaccination should be received by everyone whether those who have suffered from COVID-19 in past or those who hasn't suffered from it yet. People who are suffering from any underlying disease like diabetes, liver disease, heart disease etc. must get vaccinated to fight against COVID-19 infection. People can receive any vaccination from the available three vaccination in India as clinical trials and various studies shows that all three vaccines which are available in India are safe have enough efficacy. It is recommended that anyone if develops the serious side effects which is very rare after vaccination should seek prompt medical advice.

\section{Acknowledgement: None}

Conflict of Interest: None

Source of Funding: None 


\section{REFERENCES}

1. Wu Yeshun., Xu Xolin., Chen Zijun., et al., 2020. Nervous system involvement after infection with COVID-19 and other coronaviruses.

Sciencedirect2020.03.30.https://doi.org/10.1 016/j.bbi.2020.03.031

2. Cao Xuetao, 2020. COVID-19: immunopathology and its implications for therapy. Nature reviews immunology ,2020.04.09.

3. R. MehraMandeep., M.D., S. Sapan., et al., 2020. Cardiovascular Disease, Drug Therapy, and Mortality in Covid-19. N Engl J Med 2020; 382:e102 DOI: 10.1056/NEJMoa2007621

4. Pharmacovigilance of COVID-19 vaccines in the context of Nepal: an assessment based on early adverse drug reaction reports. Journal of Pharmaceutical Health Services Research, 2021, Vol XX, 1-3. doi:10.1093/jphsr/rmab016

5. Post Vaccination Symptoms among the Beneficieries of Covid Vaccine in Dadra \& Nagar Haveli. International Journal Dental and Medical Sciences Research. Volume 3, Issue $\quad 1, \quad$ Jan-Feb 2021. www.ijdmsrjournal.com

DOI: $10.35629 / 5252-030112151218$

6. Tauba.S., Widyati., et al., 2021 A Review of Covid-19 Vaccines: What needs to be known and its expected effect on the human population?

Preprints 2021, 2021040468https://www.preprints.org/manu script/202104.0468/v1

7. kakar A., Gogia A., et al., COVID vaccines: A step towards ending the pandemic. Current Medicine Research and Practice 2021; 11(1) : 23-30.https://cutt.ly/sbPHcAe

8. Folegatti PM, Ewer KJ, Aley PK, Angus B, Becker S, Belij-Rammerstorfer $\mathrm{S}$, et al. Safety and immunogenicity of the ChAdOx1 nCoV-19 vaccine against SARSCoV-2: A preliminary report of a phase $1 / 2$, single-blind, randomised controlled trial. Lancet 2020;396:467-78.

9. Creech, C. B., Walker, S. C., \& Samuels, R. J. (2021). SARS-CoV-2 Vaccines. JAMA.https://doi.org/10.1001/jama.2021.31 99

10. Delrue, I., Verzele, D., Madder, A., \&Nauwynck, H. J. (2012). Inactivated virus vaccines from chemistry to prophylaxis: Merits, risks and challenges. In Expert
Review of Vaccines (Vol. 11, Issue 6, pp. 695-719). https://doi.org/10.1586/erv.12.38

11. Callaway, E. (2020). The race for coronavirus vaccines: a graphical guide. Nature, 580(7805), 576-577. https://doi.org/10.1038/d41586-020-01221$\mathrm{y}$

12. Callaway, E., \&Mallapaty, S. (2021). Novavax offers first evidence that COVID vaccines protect people against variants. Nature, $\quad 590(7844), \quad 17$. https://doi.org/10.1038/d41586- 021-002689

13. Ella, R., Vadrevu, K. M., et.al., 2021. Safety and immunogenicity of an inactivated SARS-CoV-2 vaccine, BBV152: a doubleblind, randomised, phase 1 trial. The Lancet Infectious Diseases. https://doi.org/10.1016/s14733099(20)30942-7

14. Voysey, M., Clemens, et.al., 2021. Safety and efficacy of the ChAdOx1 nCoV-19 vaccine (AZD1222) against SARS-CoV-2: an interim analysis of four randomised controlled trials in Brazil, South Africa, and the UK. The Lancet, 397(10269), 99-111. https://doi.org/10.1016/S01406736(20)32661-1

15. Athavale AV., The Covid-19 Vaccine. Journal of Advanced Research and Medical Science Technology 2021; 8(1):29-35. https://doi.org/10.24321/2394.6539.202103

16. India Approves Russia's Sputnik-V Covid19 Vaccine. https://thewire.in/health/indiaapproves-russias-sputnik-v-covid-19vaccine

17. Vinod N., Stages in COVID-19 vaccine development: The Nemesis, the Hubris and the Elpis. Int J ClinVirol 2020; 4(1): 126135.

18. Zhang YJ, Zeng G, Pan HX, Li CG, Kan B, $\mathrm{Hu} \mathrm{YL}$, et al. Immunogenicity and safety of a SARS CoV 2 inactivated vaccine in healthy adults aged 1859 years: Report of the randomized, double blind, and placebo controlled phase 2 clinical trial. medRxiv $2020 \quad$ Aug; 20161216. https://doi.org/10.1101/2020.07.31.2016121 6

19. Serum Institute Registers Its Covid-19 Vaccine Trial, 21 August, 2020. Available from: https://www.hindustantimes.com. [Last accessed on 2021 Jan 09].

20. ICMR says Covaxin effective in neutralising UK strain, double mutant 
variant.21 april, 2021. https://www.hindustantimes.com/

21. Lawton.G., Sputnik V Vaccine Goes Global. New Scientist, Science direct 2021; 250 : 10-11. https://doi.org/10.1016/S02624079(21)00671-0

22. Logunov DY., et al., Safety and efficacy of an rAd26 and rAd5 vector-based heterologous prime-boost COVID-19 vaccine: an interim analysis of a randomised controlled phase 3 trial in Russia. Lancet ; February 2021; 397: 671-681. https://doi.org/10.1016/S01406736(21)00234-8

23. Dolzhikova IV., Zubkova OV., Tukhvatulin AI., et al., Safety and immunogenicity of GamEvac-Combi, a heterologous VSV- and Ad5-vectored Ebola vaccine: an open phase I/II trial in healthy adults in Russia.Hum VaccinImmunother. 2017; 13: 613-620

24. Logunov DY., Dolzhikova IV., Zubkova OV., et al.,Safety and immunogenicity of an rAd26 and rAd5 vector-based heterologous prime-boost COVID-19 vaccine in two formulations: two open, non-randomised phase $1 / 2$ studies from Russia. Lancet. 2020; 396: 887-897. https://doi.org/10.1016/S0140-6736(20)318663

25. Ikegame S., et al., Qualitatively distinct modes of Sputnik V vaccine-neutralization escape by SARS-CoV-2 Spike variants
.medRxivapril2021.https://doi.org/10.1101/2 021.03.31.21254660

26. Ostergaard DS., Schmidt M., et al., Thromboembolism and the OxfordAstraZeneca COVID-19 vaccine: sideeffect or coincidence? Lancet. 2021; 397: 14411443. https://doi.org/10.1016/S01406736(21)00762-5

27. Wise J. Covid-19: European countries suspend use of Oxford-AstraZeneca vaccine after reports of blood clots. BMJ 2021; 372: n699.

28. Wolf EM., Luz B., et al., Thrombocytopenia and Intracranial Venous Sinus Thrombosis after "COVID-19 Vaccine AstraZeneca" Exposure. J. Clin. Med.2021, 10(8), 1599; https://doi.org/10.3390/jcm10081599

29. Wise J. Covid-19: Rare immune response may cause clots after AstraZeneca vaccine, say researchers. BMJ 2021; 373: n954. https://doi.org/10.1136/bmj.n954

30. Mahase E. AstraZeneca vaccine: Blood clots are "extremely rare" and benefits outweigh risks, regulators conclude. BMJ2021;373:n931. doi:10.1136/bmj.n931 pmid:33832929

How to cite this article: Yukta, Patil RK, Patil HC. A review on vaccination drive for COVID19 in India. Int $J$ Health Sci Res. 2021; 11(8):137-142. DOI: https://doi.org/10.52403/ ijhsr.20210820 